\title{
Investigation and Analysis of Rural Medical Waste Management
}

\author{
Li Nie, Huan Wu \\ Xinxiang Medical University, Xinxiang, China \\ Email: nielily0907@126.com
}

Received 27 November 2015; accepted 17 January 2016; published 20 January 2016

Copyright (C) 2016 by authors and Scientific Research Publishing Inc.

This work is licensed under the Creative Commons Attribution International License (CC BY). http://creativecommons.org/licenses/by/4.0/

c) (i) Open Access

\begin{abstract}
Objective: The aim is to understand the status of rural medical waste management and problems and to make recommendations. Methods: The questionnaire survey, interviews and comparative analysis are used. Results: Compared with urban medical waste management, rural medical waste management is weaker in classification, unified recycle, disposals, protect measures of related personnel, regulations and policies of awareness. Conclusion: It is recommended to improve policies and regulations of rural medical waste management, strengthen rural infrastructures and facilities, improve supervision and innovates means of supervision.
\end{abstract}

\section{Keywords}

\section{Medical Waste Management, Rural Medical Institutions, Investigations}

\section{Introduction}

According to statistics of World Health Organization, 10\% - 25\% of medical waste is infectious, they bring potential environmental hazards and public health risks which have caused worldwide concern; Abdul [1] studies have shown that there are 520 million people every year, of which four million children die because medical waste exposure causes disease. Therefore, efficient waste management becomes more and more important. With the rapid development of China's economy, the number of health institutions increased from 296,492 to 974,398 in 2004 to 2013 and it increased three times in 10 years. In order to strengthen the safety management of medical waste and prevent the spread of disease, China had introduced the "medical waste management regulations" and "hospital infection management approach" in 2003 and 2006. The rules include the collection of medical waste, transport, storage, disposal and supervision and management. These policies contribute to the improvement of urban medical waste management, but there are still problems in medical waste management in rural areas. 


\section{Literature Review}

Through the questionnaire survey and interviews, medical waste management problems were found in developing countries and poor countries of abroad, Patience A. [2], Akinwale [3], Yong [4] regional studies public and private research in Ghana Hospital, Ibadan, southwest Nigeria, Korea medical waste management; Through semi-structured self-administered questionnaire survey to 131 medical staff in University of Abuja Teaching Hospital, Azuike [5] found medical waste knowledge of staff is more, but the practice is not enough; through surveys and interviews to relevant authorities and management personnel, Alam [6] and Masum A [7] indicated it was improper reasons of which awareness and financial support were lack. Joseph L. [8], Udofia [9] and Sartaj [10] have shown that the training of medical waste management should be strengthened, off-site transport should have reported, different colored containers should be used, and the necessary facilities should be increased in order to improve medical waste management normative. Balachandran P. [11] pointed out 63 percent of the medical waste was biomedical waste every year in India, which had no the facilities to deal with these wastes because of lack funds and caused random dumpty, so integrated treatment facilities should be established.

Several studies have proposed in our country. Zhang [12] et al. had a quantitative analysis of medical waste management in Nanjing through the questionnaire survey; Xu [13] and Zhang [14] et al. respectively investigated waste management research in hospital of Shandong and Gansu Province and proposed to strengthen the management of medical waste from the capital, administrative, technical aspects. In addition Cheng [15] and Li [16] researched medical staff' awareness and evaluation to medical waste management through a questionnaire survey.

In summary, there are more researches abroad literature of medical waste management and less domestic literature which focused on the urban areas. Different with the existing, this paper takes rural medical institutions in Henan Province as the object and investigates problems in order to provide evidence for improvement the medical waste management system.

\section{Data Sources and Analysis}

\subsection{Data Sources}

On the basis of questionnaire of medical waste management of World Health Organization [17], it is changed combining the status quo of China's rural. Questionnaire is designed to understand the status of medical waste management in urban and rural areas; the research objects are disposal personnel associated with medical waste including doctors, nurses and managers and so on. Medical institutions include municipal hospitals, county hospitals, township hospitals and village clinics in Henan province. Survey were carried out by colleges students of the Medical Health Service Management profession, ensured the questionnaire professional and improved the quality. We gave a comprehensive survey of medical waste including hospital insinuation, separation, collection, transport and disposal.

200 questionnaires were given in random in 2014, 136 valid questionnaires were returned, the recovery was 68\%, including 22 provincial and municipal hospitals, 38 county hospitals, 26 township-level hospitals and 50 village clinics. Descriptive statistical analysis of data is used by SPSS software.

\subsection{Questionnaire Analysis}

(1) Descriptive statistics of typical issues

It can be seen from Table 1, medical waste management in province hospitals, county, township and village showed a gradual deterioration. Such disposal methods, village clinics chose burial or incineration which accounted for $91 \%$ and indicated there is no uniform recycling in them.

(2) The questionnaire question classification

1) Classification, collection, storage and disposal of medical waste

It can be seen from Table 2, there was a lower proportion of classified in village clinics accounting for only $32 \%$; it was close to $46 \%, 47 \%$ in township and county hospitals; it was a relatively high proportion classified in province to $54.55 \%$. Medical waste classification should be further improved especially in rural areas.

For medical waste disposal, incineration accounted for $72 \%$ in village clinics, uniform recycling accounted for $24 \%$, which not met the requirements of 24 hours. Uniform recycling rate was 53.85\% in Township hospitals 
Table 1. Descriptive statistics of typical problems.

\begin{tabular}{|c|c|c|c|c|}
\hline Hospitals’ type & Village 50 & Township 26 & County 38 & Province 22 \\
\hline $\begin{array}{l}\text { Medical waste (1) infection (2) injury } \\
\text { (3) drug-induced (4) pathological (5) chemical }\end{array}$ & $\begin{array}{l}\text { options include } \\
\text { (1) } 34 \%\end{array}$ & (1) $61.53 \%$ & (1) $73.68 \%$ & (1) $92 \%$ \\
\hline $\begin{array}{l}\text { Protective measures or special gloves } \\
\text { (1) yes (2) no }\end{array}$ & $\begin{array}{l}\text { (1) } 74 \% \\
\text { (2) } 26 \%\end{array}$ & $\begin{array}{l}\text { (1) } 57.69 \% \text {, } \\
\text { (2) } 42.31 \%\end{array}$ & $\begin{array}{l}\text { (1) } 55.26 \% \text {, } \\
\text { (2) } 44.74 \%\end{array}$ & $\begin{array}{l}\text { (1) } 45.45 \% \text {, } \\
\text { (2) } 54.55 \%\end{array}$ \\
\hline $\begin{array}{l}\text { Treatment: (1) nearby landfill (2) dumping } \\
\text { (3) nearby incineration (4) uniform recycling }\end{array}$ & $\begin{array}{l}\text { (1) (2) } 91 \% \text {, } \\
\text { (3) } 9 \%\end{array}$ & $\begin{array}{l}\text { (1) (2) } 19.23 \% \text {, } \\
\text { (3) } 19.23 \%, \text { (4) } 61.53 \%\end{array}$ & $\begin{array}{l}\text { (1) } 26.32 \% \text {, } \\
\text { (4) } 73.68 \%\end{array}$ & (4) $100 \%$ \\
\hline Management person: (1) yes (2) no & $\begin{array}{l}\text { (1) } 17 \% \\
\text { (2) } 83 \%\end{array}$ & $\begin{array}{l}\text { (1) } 42.3 \% \text {, } \\
\text { (2) } 57.7 \%\end{array}$ & $\begin{array}{l}\text { (1) } 76.32 \% \text {, } \\
\text { (2) } 23.68 \%\end{array}$ & (1) $100 \%$ \\
\hline Newly trained staff (1) yes (2) no & $\begin{array}{l}\text { (1) } 57 \% \text {, } \\
\text { (2) } 43 \%\end{array}$ & $\begin{array}{l}\text { (1) } 34.62 \% \text {, } \\
\text { (2) } 65.38 \%\end{array}$ & $\begin{array}{l}\text { (1) } 44.74 \% \text {, } \\
\text { (2) } 55.26 \%\end{array}$ & $\begin{array}{l}\text { (1) } 85 \% \text {, } \\
\text { (2) } 15 \%\end{array}$ \\
\hline Awareness waste regulations (1) yes (2) no & $\begin{array}{l}\text { (1) } 34 \% \text {, } \\
\text { (2) } 66 \%\end{array}$ & $\begin{array}{l}\text { (1) } 19.23 \% \text {, } \\
\text { (2) } 80.77 \%\end{array}$ & $\begin{array}{l}\text { (1) } 21.05 \% \text {, } \\
\text { (2) } 78.95 \%\end{array}$ & $\begin{array}{l}\text { (1) } 40 \% \text {, } \\
\text { (2) } 60 \%\end{array}$ \\
\hline Manual or guide (1) yes (2) no & (1) $100 \%$ & $\begin{array}{l}\text { (1) } 11.54 \% \text {, } \\
\text { (2) } 88.46 \%\end{array}$ & $\begin{array}{l}\text { (1) } 42.11 \% \text {, } \\
\text { (2) } 57.89 \%\end{array}$ & $\begin{array}{l}\text { (1) } 35 \% \text {, } \\
\text { (2) } 65 \%\end{array}$ \\
\hline Long-term plan of management (1) yes (2) no & (2) $100 \%$ & (2) $100 \%$ & $\begin{array}{l}\text { (1) } 5.26 \% \text {, } \\
\text { (2) } 94.74 \%\end{array}$ & $\begin{array}{l}\text { (1) } 38.56 \text {, } \\
\text { (2) } 61.44 \%\end{array}$ \\
\hline Teams (1) yes (2) no & I & (2) $100 \%$ & $\begin{array}{l}\text { (1) } 15.79 \% \text {, } \\
\text { (2) } 84.21 \%\end{array}$ & $\begin{array}{l}\text { (1) } 45.45 \% \text {, } \\
\text { (2) } 54.54 \%\end{array}$ \\
\hline Internal supervisory staff (1) yes (2) no & $\begin{array}{l}\text { (1) } 48 \% \text {, } \\
\text { (2) } 52 \%\end{array}$ & $\begin{array}{l}\text { (1) } 23.08 \% \text {, } \\
\text { (2) } 76.92 \%\end{array}$ & $\begin{array}{l}\text { (1) } 39.47 \% \text {, } \\
\text { (2) } 60.53 \%\end{array}$ & $\begin{array}{l}\text { (1) } 37 \% \text {, } \\
\text { (2) } 53 \%\end{array}$ \\
\hline External supervisory staff (1) yes (2) no & $\begin{array}{l}\text { (1) } 34 \% \text {, } \\
\text { (2) } 66 \%\end{array}$ & $\begin{array}{l}\text { (1) } 42.3 \% \text {, } \\
\text { (2) } 57.7 \%\end{array}$ & $\begin{array}{l}\text { (1) } 34.21 \% \text {, } \\
\text { (2) } 65.79 \%\end{array}$ & $\begin{array}{l}\text { (1) } 37 \% \text {, } \\
\text { (2) } 53 \%\end{array}$ \\
\hline
\end{tabular}

Table 2. Classification, collection, storage and disposal of medical waste.

\begin{tabular}{ccccc}
\hline Questions type & Village $\mathrm{n}=50(\%)$ & Township $\mathrm{n}=26(\%)$ & Country $\mathrm{n}=38(\%)$ & Province $\mathrm{n}=22(\%)$ \\
\hline Classification & $16(32)$ & $12(46.15)$ & $18(47.37)$ & $12(54.55)$ \\
Label in container & $6(12)$ & $4(15.38)$ & $6(15.79)$ & $12(54.55)$ \\
Tool in the tool box & $6(12)$ & $4(15.38)$ & $8(21.05)$ & $18(81.82)$ \\
Disposal & & & & $0(0)$ \\
Nearby landfill & $10(20)$ & $2(7.69)$ & $0(0)$ & $0(0)$ \\
Nearby incineration & $36(72)$ & $4(15.38)$ & $10(26.32)$ & $0(0)$ \\
Dumping & $12(24)$ & $6(23.08)$ & $0(0)$ & $22(100)$ \\
Uniform recycling & $12(24)$ & $14(53.85)$ & $28(73.68)$ & $22(100)$ \\
Correct recycle time & $0(0)$ & $2(7.69)$ & $12(31.58)$ & \\
\hline
\end{tabular}

and only $7.69 \%$ of the medical waste recycling was the stipulated time. Due to the distance and other factors, ratio of county hospitals did not reach $100 \%$.

2) Personnel protective measures and training of medical waste

For protective measures, such as Table 3, the protective proportion of village clinics is highly $68 \%$, it is $52 \%$ $-53 \%$ and slightly lower in the township and county hospitals, the highest proportion of and municipal is $81.82 \%$; whether are training in old and new staff, the proportion of village clinics is higher than it of township and county hospitals and it is highest in provincial hospitals. According to village clinics, township, county and provincial levels, it is from $44 \%$ to $54.55 \%$ of job duties description and is showing growth trend.

3) Regulations and policies of medical waste

For regulatory awareness, as shown in Table 4, the proportion was 44 in village, it is $30.77 \%$ and $26 \%$ in township and county and provincial ratio was higher accounting for $54.55 \%$. The proportion of developing guidelines is low in village and township institutions, it is higher in county and provincial hospitals, but the overall ratio is not high. Village and township hospitals have not long-term plans, provincial $15.79 \%$ hospitals have long-term plan and $36.36 \%$ provincial hospitals have long-term plans; village and township level have a lower proportion of the team and it is high in province hospitals; Provincial hospitals have internal supervisory, 
Table 3. Personnel protective measures and training of medical waste.

\begin{tabular}{ccccc}
\hline Questions type & Village $\mathrm{n}=50(\%)$ & Township $\mathrm{n}=26(\%)$ & Country $\mathrm{n}=38(\%)$ & Province $\mathrm{n}=22(\%)$ \\
\hline protection and gloves & $34(68)$ & $14(53.85)$ & $20(52.63)$ & $18(81.82)$ \\
Training & $26(52)$ & $10(38.46)$ & $16(42.11)$ & $14(63.64)$ \\
Training of new staff & $28(56)$ & $12(46.15)$ & $16(42.11)$ & $18(81.82)$ \\
Job duties description & $22(44)$ & $14(53.85)$ & $18(47.37)$ & $12(54.55)$ \\
\hline
\end{tabular}

Table 4. Regulations and policies of medical waste.

\begin{tabular}{ccccc}
\hline Questions type & Village $\mathrm{n}=50(\%)$ & Township $\mathrm{n}=26(\%)$ & Country $\mathrm{n}=38(\%)$ & Province $\mathrm{n}=22(\%)$ \\
\hline List regulations and policies & $22(44)$ & $8(30.77)$ & $10(26.32)$ & $12(54.55)$ \\
Manual or guide & $32(64)$ & $12(46.15)$ & $24(63.16)$ & $20(90.9)$ \\
- Country rule & $11(44)$ & $10(38.46)$ & $12(31.58)$ & $12(54.55)$ \\
Hospital rule & $10(20)$ & $2(7.69)$ & $12(31.58)$ & $10(45.4)$ \\
Long time plan & $0(0)$ & $0(0)$ & $6(15.79)$ & $6(36.36)$ \\
Management team & $2(4)$ & $2(7.69)$ & $12(15.79)$ & $14(63.64)$ \\
Internal supervision staff & $10(20)$ & $6(23.08)$ & $10(26.32)$ & $12(54.54)$ \\
external supervision staff & $12(24)$ & $8(30.77)$ & &
\end{tabular}

it is $54.55 \%$ and the ratio is not too high; external supervision of village, township and county supervision were $20 \%$, $23 \%$ and $31.58 \%$; external supervision of provincial is relatively high $63.64 \%$.

\section{Discussions and Recommendations}

Because original records of medical management lacked especially in rural instantiations, the results were got only by workers. Perhaps a few data could not be received.

Taken "reduce, reuse, recycle" as the goal, from recycling systems sustainable development of rural medical waste, reducing pollution and hazard, focusing on improving the scientific, normative and systemic management of medical waste, We propose the following recommendations.

(1) Improve the rural medical waste management policies and regulations to enhance operability

Compared to rural and urban areas, rules and regulations of medical waste management are relative lack, rural medical institutions have not their own rules and regulations, specific job responsibilities are not be requested for medical waste management staff and professional knowledge is lack.

On the basis of "Medical Waste Management Regulations" in 2003 and "To further strengthen supervision of hazardous waste and medical waste Work" in 2011, government should promote legislation of rural medical waste management, emphasize on rural medical waste classification and recycling and develop implemented management measures. Owning to classification, registration, emergency programs of rural medical waste, local governments and medical institutions should improve the complete set of implementation rules, guidelines and guidance, and increase regulations operability.

(2) Strengthen infrastructure and supporting facilities of rural medical waste

Compared with the urban hospitals, there are a few problems of rural medical waste classification, container labeling of infectious medical waste and tools into special containers, especially in village clinics. Owning to the final disposal, there are some problems such as disposal itself and non-standard disposal and no uniform recycling especially in village institutions, which free to deal in medical waste and random dumping phenomenon exist. Some disposable infusion bottles are unauthorized traded in township hospitals.

We should accelerate construction of the temporary storage. It is the key problem in rural medical waste recycling system that rural medical institutions are far apart and uniform recycling is more difficult, so to complete the build rural medical storage soon as possible; while the government should strengthen constructions medical waste facilities such as recycling containers. 
So we should to build the temporary storage in rural medical institutions as soon as possible, at the same time, the government and hospitals should strengthen the establishment of medical waste facilities, such as recovery special containers.

(3) Strengthen supervision, improve the supervision mechanism and innovate means of supervision

We should strengthen supervision and improve the supervision mechanism. Local governments, environmental protection departments, health authorities and medical institutions should further clarify the relevant functional orientation and well-defined power and responsibility, format a supervision and management system of government-led cooperation with each other, improve the relevance and validity checking and increase management efficiency of rural medical waste; while supervision and inspection should be normalized and strengthened efforts and we should implement evaluation mechanisms and take the qualification rate of medical waste management into performance assessment indicators of local government environment.

Government should innovate means of supervision, build information technology platform of rural medical waste management using information technology such as the Internet of things, two dimensional barcode, camera, GPS, and improve files of rural medical institutions and management company and emergency decision system, realize electronic tracking supervision in the whole process from classification, collection, transportation to the final disposal as soon as possible and improve the efficiency of supervision. Government should regularly announce inspect results, promote information disclosure of the enthusiasm of public participation in supervisions and promote the supervision of public opinions.

\section{Fund}

Scientific Research Fund of Xinxiang Medical University (No. 2013QN202).

\section{References}

[1] Ambali, A.R. and Bakar, N. (2012) MWM in Malaysia: Policies, Strategies and Issues IEEE Colloquium on Humanities. Science \& Engineering Research, 10, 3-4.

[2] Abor, P.A. (2013) Managing Healthcare Waste in Ghana: A Comparative Study of Public and Private Hospitals. International Journal of Health Care Quality Assurance, 26, 375-386.

[3] Coker, A., Sangodoyin, A. and Sridhar, M. (2009) Medical Waste Management in Ibadan, Nigeria: Obstacles and Prospects. Waste Management, 29, 804-811.

[4] Jang, Y.-C., Lee, C., Yoon, O.-S. and Kim, H. (2006) Medical Waste Management in Korea. Journal of Environmental Management, 80, 107-115. http://dx.doi.org/10.1016/j.jenvman.2005.08.018

[5] Azuike, E.C., Adinma, E.D., Nwabueze, S.A., et al. (2015) Healthcare Waste Management: What Do the Health Workers in a Nigerian Tertiary Hospital Know and Practice. Science, 3, 114-118.

[6] Alam, M.Z., Islam, M.S. and Islam, M.R. (2015) Medical Waste Management: A Case Study on Rajshahi City Corporation in Bangladesh. Journal of Environmental Science and Natural Resources, 6, 173-178. http://dx.doi.org/10.3329/jesnr.v6i1.22062

[7] Patwary, M.A., O’Hare, W.T. and Sarker, M.H. (2012) Medical Waste Workers in Bangladesh. Safety Science, 1, 7682.

[8] Joseph, L., Paul, H., Premkumar, J., et al. (2015) Biomedical Waste Management: Study on the Awareness and Practice among Healthcare Workers in a Tertiary Teaching Hospital. Indian Journal of Medical Microbiology, 33, 129. http://dx.doi.org/10.4103/0255-0857.148411

[9] Udofia, E.A., Fobil, J.N. and Gulis, G. (2015) Solid Medical Waste Management in Africa. African Journal of Environmental Science and Technology, 9, 244-254. http://dx.doi.org/10.5897/AJEST2014.1851

[10] Sartaj, M. and Arabgol, R. (2015) Assessment of Healthcare Waste Management Practices and Associated Problems in Isfahan Province (Iran). Journal of Material Cycles and Waste Management, 17, 99-106. http://dx.doi.org/10.1007/s10163-014-0230-5

[11] Balachandran, P. (2015) Integrated Biomedical Waste Management for Small Scale Healthcare Units in India. In: Van Toi, V. and lien, T.H., Eds., 5th International Conference on Biomedical Engineering in Vietnam. Springer International Publishing, Switzerland, 458-460.

[12] Zhang, Y., Xiao, G. and Wang, G.X., et al. (2009) Medical Waste Management in China: A Case Study of Nanjing. Waste Management, 29, 1376-1382. http://dx.doi.org/10.1016/j.wasman.2008.10.023

[13] Xu, L.Z., Wang, X.Z. and Zhang, Y.F., et al. (2009) Hospital Medical Waste Management in Shandong Province, 
China. Waste Management \& Research, 27, 336-342. http://dx.doi.org/10.1177/0734242X09104384

[14] Zhang, H.-J., Zhang, Y.-H., Wang, Y., et al. (2013) Investigation of Medical Waste Management in Gansu Province, China. Waste Management \& Research, 31, 655-659. http://dx.doi.org/10.1177/0734242X13482161

[15] Cheng, B.L. (2014) The Medical Workers on the Current Status of the Medical Waste Management Cognitive Attitude and Evaluation Research. Journal of Community Medical Journal, 19, 60-62.

[16] Li, H.J., Tang, Z.X., Xu, L.Z., et al. (2008) Cognition and Attitude of Medical Staff of Medical Waste Management Analysis. Chinese Health Economy, 27, 49-51.

[17] Prüss, A., Giroult, E. and Rushbrook, P. (1999) Safe Management of Wastes from Health-Care Activities. World Health Organization, Geneva, 11-12. 